\title{
VIVÊNCIAS NEGRAS E TRABALHO DO CUIDADO: UMA ANÁLISE CONSUBSTANCIAL SOBRE AS TRAJETÓRIAS DE MULHERES NEGRAS NO MERCADO DE TRABALHO EM CAMPOS DOS GOYTACAZES/RJ
}

\author{
BLACK LIVING AND CARE WORK: A CONSUBSTANTIAL ANALYSIS OF THE \\ TRAJECTORIES OF BLACK WOMEN IN THE LABOR MARKET IN CAMPOS DOS \\ GOYTACAZES/RJ
}

\author{
Pauline Aparecida Ildefonso Ferreira da Silva ${ }^{1}$ \\ Érica Terezinha Vieira de Almeida ${ }^{2}$
}

\section{RESUMO}

Este artigo é fruto de pesquisa realizada no ano de 2018 e tem como finalidade problematizar a consubstancialidade, ou seja, a interdependência das relações sociais de classe, gênero e raça na produção da desigualdade social, tendo como referência empírica a inserção da mulher negra no mercado de trabalho em Campos dos Goytacazes/RJ, município cuja economia se sustentou, historicamente, no binômio escravidão/monocultura da cana-de-açúcar. Nesse sentido, além da pesquisa bibliográfica e fontes secundárias, também foram realizadas entrevistas semiestruturadas com mulheres de distintas idades e gerações. Esta última foi fundamental para confirmarmos os vínculos entre modernização e desigualdade de classe, gênero e raça, sobretudo nas décadas seguintes à abolição até os anos 2000 e sua atenuação a partir de então, com a efetivação das políticas sociais, particularmente aquelas relacionadas à renda e à educação.

Palavras-chave: mulheres negras, trabalho do cuidado, Campos dos Goytacazes/RJ, políticas públicas.

\begin{abstract}
This article is the result of research carried out in 2018 and aims to problematize consubstantiality, that is, the interdependence of social relations of class, gender and race in the production of social inequality, having as an empirical reference the insertion of black women in the market in Campos dos Goytacazes / RJ, a municipality whose economy has historically been sustained in the binomial slavery / monoculture of sugarcane. In this sense, in addition to bibliographic research and secondary sources, semi-structured interviews were also conducted with women of different ages and generations. The latter was essential to confirm the links between modernization and inequality of class, gender and race, especially in the decades following the abolition until the 2000s and its attenuation since then, with the implementation of social policies, particularly those related to income and education.
\end{abstract}

Keywords: black women, care work, Campos dos Goytacazes/RJ. public policies.

\footnotetext{
Assistente Social, Historiadora, doutoranda em Políticas Sociais pela Universidade Estadual do Norte Fluminense - Darcy Ribeiro.

2 Assistente Social, Doutora em Serviço Social e Professora do Curso de Serviço Social e do Programa de Pós-Graduação em Desenvolvimento Regional, Ambiente e Políticas Públicas, ambos da UFF - Campos dos Goytacazes/RJ. Coordenadora do NETRAD (Núcleo de Pesquisa em Dinâmica Capitalista e Ação Política) e-mail: ericalmeida@uol.com.br.
} 


\section{INTRODUÇÃO}

As reflexões que apresentamos neste trabalho dizem respeito ao lugar da mulher negra na produção e reprodução da vida na sociedade capitalista, face aos arranjos contemporâneos do mercado de trabalho. Embora as pesquisas atuais tenham ampliado o debate sobre a interseccionalidade e a consubstancialidade nas relações sociais, mediadas pelo mercado de trabalho, neste artigo procuramos enfatizar as particularidades locais e regionais, no contexto de desenvolvimento desigual e combinado (LOWY, 1998; MARINI, 19790; GONZALEZ, 1979), que caracterizam a subordinação dos países de capitalismo periférico. Para tanto, propomos uma revisão bibliográfica sobre a perspectiva da interseccionalidade e da consubstancialidade das relações de classe, gênero e raça na produção das relações sociais, no passado, e sua reatualização contemporânea, assim como da formação do mercado de trabalho urbano em Campos dos Goytacazes, principal município da Região Norte Fluminense, no Estado do Rio de Janeiro. Para tal, foram realizadas algumas entrevistas semiestruturadas com um grupo de trabalhadoras negras, de diferentes gerações, que vivenciaram os processos de transformação no mercado de trabalho na região, particularmente na cidade de Campos dos Goytacazes, objeto desta análise. A intenção da pesquisa qualitativa não foi outra senão a de revelar as cadeias de subordinação e/ou rupturas na condição das mulheres negras e empobrecidas, em sua maioria, inseridas nos trabalhos do cuidado (COLLINS, 2015) especialmente, após os ciclos de expropriação do campo, a partir dos anos de 1950, e que foram responsáveis pela criação do mercado de trabalho urbano.

Considerando incialmente os debates acadêmicos relativos à pluralidade das relações sociais e, principalmente, aos decorrentes das experiências dos movimentos feministas negros, a partir dos anos de 1960, sobre a interdependência/interseccionalidade das relações de classe, gênero e raça (CRENSHAW, 2002) na produção das desigualdades sociais, foi possível ampliar e aprofundar a compreensão desses fenômenos. Com base em uma perspectiva analítica interseccional e consubstancial, ou seja, de uma abordagem na qual essas três formas de opressão e desigualdade aparecem combinadas sem uma assimetria à priori, foi possível problematizar a situação da mulher negra no mercado de trabalho no município de Campos dos Goytacazes. Para Hirata (2014), o conceito de consubstancialidade não só possibilita pensar as dominações de forma conjunta como também contribui para o fim da reprodução das mesmas. Em outras palavras, a abordagem da consubstancialidade não só torna compreensível a divisão social e sexual do trabalho, mas, também, as suas particularidades no contexto do racismo estrutural.

Este artigo dividir-se-á em três sessões: A primeira, dedicada à abordagem da interseccionalidade/consubstancialidade, tem como objetivo apresentar o debate teóricometodológico sobre o conjunto de conceitos que serão utilizados, de modo a contribuir para a apropriação do debate sobre classe, gênero e raça na produção e reprodução das desigualdades sociais e da opressão, com ênfase na literatura sobre o mercado de trabalho e, particularmente, o trabalho do cuidado. A segunda sessão resgata dados sobre o mercado de trabalho local visà-vis com o mercado nacional, destacando a força de trabalho feminina e negra, tendo como referência o Retrato das Desigualdades de Gênero e Raça (IPEA, 2017), o Relatório Anual das Desigualdades Raciais no Brasil, 2007-2008 (PAIXÃO; CARVANO, 2010), e também os estudos de Almeida e Monteiro (2011) e Almeida e Rangel (2014), referentes aos beneficiários do Programa Bolsa Família em Campos. A esse conjunto de fontes, foram acrescentados os relatos das entrevistas com as trabalhadoras negras, de modo a recuperar as consubstancialidades do mercado de trabalho local, por meio das experiências dessas mulheres e suas representações. Segundo Alberti, a história oral "decorre de toda uma postura com relação à história e às configurações socioculturais, que privilegia a recuperação do vivido, conforme concebido por 
quem viveu" (1990, p. 5). Ao optar por essa metodologia de pesquisa não só avançamos para além daquilo que os dados quantitativos são capazes de nos apresentar, como também temos a possibilidade de ultrapassar realidades abstratas e genéricas, com base nas experiências e relações concretas de subjugações e opressões.

Dando continuidade, a terceira e última sessão traz os relatos de vida e trabalho de cinco mulheres negras de idades distintas, em uma perspectiva geracional. Além de complementarem as informações sobre a formação da classe trabalhadora urbana em Campos dos Goytacazes, as entrevistas priorizam a consubstancialidade das relações de classe, gênero e raça e os meios pelos quais estas estruturam os processos de dominação/exploração na sociedade campista. Percebemos que o trabalho do cuidado tornou-se "caminho comum" para as gerações anteriores de mulheres negras que tiveram seus direitos negados ao acesso a bens e serviços sociais, ao longo de suas vidas. Como já era esperado, os relatos das mulheres idosas expõem maior precarização no contexto familiar, educacional e do trabalho, já que são produtos de contextos mais vulneráveis, de forte presença das relações patriarcais e do racismo estrutural, assim como da completa ausência de proteção social pública. Por outro lado, o acesso das gerações mais jovens a melhores condições de vida e de trabalho, está diretamente ligado à ampliação e ao fortalecimento das políticas públicas nos últimos trinta anos, em especial aquelas de transferência de renda e de educação. Embora tenhamos alcançado níveis melhores de escolaridade, de trabalho e de renda, os desafios postos às mulheres negras no sentido de romper com as cadeias históricas de subordinação ainda são reais e persistentes neste século.

\section{DESENVOLVIMENTO}

\subsection{Relações sociais e interseccionalidade: um olhar de equidade sobre as vivências negras}

O amadurecimento do pensamento feminista sobre as complexidades das relações sociais avança entre os anos de 1980 e 1990, com a formulação do primeiro conceito articulador de gênero, raça e classe chamado "Black Feminist" ou Feminismo Negro, que quebrou paradigmas instituídos sob o próprio movimento feminista, inserindo novos parâmetros sobre suas teorias e lutas, por meio do "Standpoint", e dialética das vivências negras. Como salienta Davis (2013), faz-se necessário um olhar que traga a equidade histórica sobre a trajetória da mulher negra. Segundo a autora, não se trata apenas de uma questão ética, mas do reconhecimento do que ela chama de "ligações históricas", ou seja, das relações sociais que resistem através do tempo, influenciando e dando forma às muitas outras relações sociais e impedindo que se avance na construção de uma sociedade livre do racismo estrutural, da desigualdade de gênero e das desigualdades de classe. Era preciso denunciar as "cadeias de subordinação", denuncia Crenshaw (1989), nas quais a mulher negra está inserida, assim como as formas na qual o sistema capitalista de produção se alimenta das desigualdades e opressões de gênero, raça e classe, convergindo para que gerações de mulheres negras continuem em condições de subalternidade. Ao discutirem sobre o status de outsider within nas suas análises sobre as trabalhadoras domésticas afro-americanas na década de 1980, Collins (2016) e Hooks (2013) afirmam que a posição de outsider within possibilitava uma compreensão multidimensional da vida. Essas e outras mulheres foram pioneiras na práxis do

\footnotetext{
3 Sabedoria coletiva sobre como viver como mulheres negras, nos Estados Unidos deu forma a um ponto de vista particular a respeito de padrões específicos de gêneros na segregação racial e as sanções econômicas deles recorrentes [...] respostas diversas a estas questões centrais caracterizam o standpoint (COLLINS, 2019).
} 
feminismo negro e no processo de formulação do conceito de interseção ou interseccionalidade, tornando-se assim a primeira teoria de articulação das múltiplas formas de opressão e dominação que tem como base de análise o passado escravista e o racismo pós-emancipação civil dos negros e negras norte-americanos.

Segundo Kergoat (2010), a consubstancialidade trata da articulação e interdependência das relações sociais fundamentais representadas pelas relações de gênero, raça e classe. Ainda segundo a autora,

As relações sociais são consubstanciais; elas formam um nó que não pode ser desatado no nível das práticas sociais, mas apenas na perspectiva da análise sociológica; e as relações sociais são coextensivas: ao se desenvolverem, as relações sociais de classe, gênero e "raça" se reproduzem e se coproduzem mutuamente (KERGOAT, 2010, p. 20).

O termo consubstancialidade remete à unidade de substância entre três entidades distintas, e nos convida a pensar o mesmo e o diferente em um só movimento (KERGOAT, 2016). Segundo a autora, a escolha do termo, quase de forma natural, é uma analogia com relação à ideia da Santíssima Trindade. De acordo com ela,

\begin{abstract}
Seu empréstimo da teologia não era evidente, embora utilize aqui em sua acepção mais banal, que enuncia a unidade e a identidade de substâncias das três pessoas da trindade: o Pai, o Filho e o Espírito Santo. Ele significa a unidade de substâncias entre três entidades distintas, convida a pensar o mesmo e o diferente em um só movimento. Não obstante sejam distintas, as relações sociais têm propriedades comuns - daí o emprego do conceito marxiano de relação social com seu conteúdo dialético e materialista para se pensar, também, sexo e raça. As relações sociais embora distintas não podem ser pensadas separadamente, sob o risco de serem reificadas (2016, p. 20).
\end{abstract}

A consubstancialidade, como uma lente para a leitura das relações sociais, permite uma análise mais aproximada das condições objetivas das mulheres negras e pobres inseridas em uma sociedade extremamente desigual, como é o caso do Brasil. Ao afirmarem que a "classe trabalhadora tem dois sexos", Hirata e Kergoat (2007) chamam a atenção para a divisão social e sexual do trabalho, sem, contudo, negar a presença das assimetrias e violências de natureza étnico-racial presentes nas sociedades contemporâneas e expressas, sobretudo, no mercado de trabalho e na representação política. Segundo as referidas autoras,

A divisão sexual do trabalho é a forma de divisão do trabalho social decorrente das relações sociais entre os sexos; mais do que isso, é um fator prioritário para a sobrevivência da relação social entre os sexos. Essa forma é modulada histórica e socialmente. Tem como características a designação prioritária dos homens à esfera produtiva e das mulheres à esfera reprodutiva e, simultaneamente, a apropriação pelos homens das funções com maior valor social adicionado - políticos, religiosos, militares etc. (HIRATA; KERGOAT, 2007, p. 599).

Enquanto perspectiva analítica, a consubstancialidade permite o aprofundamento teórico nos estudos que contemplam gênero, raça/cor e classe como agentes contínuos, como define Falquet (2008) na construção das trajetórias de vida, levando Kergoat (2016) a assegurar que do mesmo modo que a noção de interseccionalidade, a consubstancialidade remete a dois objetivos: o reconhecimento dos diferentes mecanismos de opressão, o qual requer que sua complexidade não seja negada; e o da emancipação como horizonte.

Em sociedades de profundas desigualdades tanto por gênero quanto por raça, o gênero sempre resulta como categoria racial e a raça como categoria de gênero. Desta forma, há que se 
pensar na complementariedade de gênero, raça e classe nas relações sociais. Em países como o Brasil, por exemplo, faz sentido pensar as desigualdades de classe sempre articuladas com as desigualdades de cor/raça, tendo em vista o passado escravagista que determina as classes com base nos critérios raciais. É importante pensar como essas relações continuam atuais, desdobrando-se nos diferentes contextos de reprodução da vida. O desemprego, a precarização do trabalho, os baixos níveis de escolaridade, e mais precisamente a maciça inserção da força de trabalho negra no trabalho do cuidado, são alguns dos exemplos dessa interseccionalidade das relações.

No que se refere ao conceito de trabalho, paulatinamente, a teoria feminista vem caminhando para uma definição de trabalho que se distancia da perspectiva de trabalho enquanto "simples produção de objetos", em direção às abordagens ontológicas que concebem o trabalho como a "produção do viver em sociedade" (KERGOAT, 2016, p. 18). Desta forma, seria um equívoco tomar de forma isolada as reflexões que perpassam as questões de gênero, raça e classe, principalmente quando se trata de analisar tais relações mediadas pelo mercado de trabalho, meio privilegiado onde se estabelecem as múltiplas relações de poder por meio da divisão social, sexual e racial do trabalho.

A distinção entre relação intersubjetiva e relação social permite compreender que, se a situação mudou de fato em matéria de relações intersubjetivas entre os sexos e nos casais, as relações sociais, porém, continuam a operar e a se manifestar sob suas três formas canônicas: exploração, dominação e opressão (que podem ser ilustradas pelas diferenças salariais, pela maior vulnerabilidade e maior risco de ser vítima de violências). Ou seja, se de um lado há um deslocamento das linhas de tensão, de outro, as relações sociais de sexo permanecem intactas. Da mesma maneira, são as práticas sociais — e não as relações intersubjetivas — que podem dar origem a formas de resistência e que podem, portanto, ser as portadoras de um potencial de mudança no nível das relações sociais (KERGOAT, 2010, p. 95).

Pensar as consubstancialidades no mercado de trabalho permite trazer ao centro do debate as bases histórico-sociais que o formou. Para tanto, faz-se necessário atualizar e particularizar o debate em torno do conceito de classe e da classe trabalhadora sob as recentes mudanças ocorridas no mercado de trabalho, de modo a complementar as novas e antigas demandas, as heterogeneidades de raça e de gênero, assim como as configurações contemporâneas da classe trabalhadora (ALMEIDA; ILDEFONSO, 2017). Soma-se a isto a questão racial no Brasil, já que o racismo se afirma como um importante marcador das relações sociais. Segundo Gonzalez (1979), o racismo enquanto "praxis" útil ao capital constitui-se em um sistema de práticas que legitima a sociedade de classe brasileira.

O racismo, enquanto articulação ideológica e conjunto de práticas, denota sua eficácia estrutural na medida em que remete à divisão racial do trabalho, extremamente útil e compartilhado pelas formações socioeconômicas capitalistas e multirraciais contemporâneas. Em termos de manutenção de equilíbrio do sistema como um todo, ele é um dos critérios de maior importância na articulação dos mecanismos de recrutamento para as posições na estrutura de classe e no sistema de estratificação social (GONZALEZ, 1979, p. 3).

Portanto, a estreita relação entre raça e classe social que permeia a formação da sociedade capitalista no Brasil precisa ser considerada, nas atuais configurações do mundo do trabalho assalariado, mantendo a força de trabalho feminina negra atrelada às atividades de menor prestígio social e de menores remunerações. 
Além disso, o conceito de trabalho, na teoria feminista, a partir dos anos 1970, também sofreu profunda alteração, abrindo novas possibilidades para se pensar "os trabalhos", sobretudo, o "trabalho doméstico e de reprodução dos seres humanos", "o trabalho militante", "o trabalho doméstico de saúde" e "o trabalho de cuidado". De acordo com Kergoat,

O cuidado não é apenas uma atividade sem intenção, é um trabalho que abrange um conjunto de atividades materiais e de relações que consistem em oferecer resposta concreta às necessidades dos outros. Assim, podemos defini-lo como uma relação de serviço, apoio e assistência, remunerada ou não, que implica um sentido de responsabilidade em relação à vida e ao bem-estar de outrem (2016, p. 17).

Esse último se aproxima mais das intenções desse trabalho. Sob o ponto de vista destas novas análises, o trabalho da mulher não pode ser fracionado entre trabalho produtivo e não produtivo, mas em trabalho visível e invisível, ou se preferirmos, em reconhecido e não reconhecido, pago ou gratuito, embora todos sejam úteis ao capital. Mesmo que todo trabalho exija o emprego de tempo ou da força, nem todos estão atrelados ao assalariamento. "O assalariamento constitui a linha divisória entre empregos visíveis, identificáveis, pagos, e trabalhos informais, ocultos na penumbra das atividades domésticas ou agrícolas, que nem sempre são pagos" (MARUANI; MERON, 2016, p. 59).

Nesta perspectiva feminista materialista (KERGOAT, 2016), é a própria definição de trabalho que implode. Não implode, porém, no sentido de "botar abaixo" a existência do proletariado e das classes sociais. Implode enquanto conceito engessado, que desmerece as novas determinações e composições da classe trabalhadora no curso da história. Sendo assim, o trabalho, nesta análise, não perde a sua centralidade como elemento estruturante da vida social e, nem tampouco, da reprodução ampliada do capitalismo, mesmo no seu atual regime de acumulação flexível, sob o comando das finanças. É neste sentido que Antunes e Alves (2004) reafirmam a importância de considerar as metamorfoses no mundo do trabalho e sua fragmentação, sobretudo no contexto atual da mundialização do capital, e pensar o conceito ampliado de classe trabalhadora, compreendida como

A totalidade dos assalariados, homens e mulheres que vivem da venda da sua força de trabalho, não se restringindo aos trabalhadores manuais diretos, incorporando também a totalidade do trabalho social, a totalidade do trabalho coletivo que vende sua força de trabalho como mercadoria em troca de salário (2004, p. 342).

Embora tal definição represente um avanço para as análises que consideram as determinações conjuntas dos conceitos analisados, não podemos ignorar que essa abertura sobre o conceito de trabalho, que, segundo Kergoat (2016), confere dignidade ao trabalho do cuidado, não salvaguarda o fato de que esse trabalho é também, em sua maioria, trabalho não qualificado, mal pago, não reconhecido e simbolicamente uma obrigação da mulher fazê-lo.

Além disso, a experiência de trabalho das mulheres pobres é marcada pelo trabalho doméstico ou em domicílio. Ainda hoje o trabalho doméstico remunerado é uma das principais ocupações femininas, sobretudo das mulheres negras, que há muito tempo já trabalham fazendo serviços de costura, lavando roupa para fora, cozinhando para vender, cuidando das pessoas (MORENO, 2015, p. 48).

O que as trabalhadoras do cuidado têm em comum? Todas estão em situação precária e majoritariamente são mulheres. Desta forma, fica evidente a necessidade de se pensar as imbricações entre os conceitos de gênero, raça e classe se quisermos compreender "o movimento que atravessa os espaços-tempos do cuidado globalizado" (KERGOAT, 2016, p. 19). 
O trabalho do cuidado está atrelado a outra categoria importante e que historicamente se aproxima das experiências das trabalhadoras negras. $\mathrm{O}$ forte legado racista e patriarcal familiar e institucional que define e estabelece os "lugares" na sociedade com base em papéis bem definidos e distintos, inseriu as mulheres negras nos espaços domésticos. Desta forma, o trabalho da mulher negra tem como herança colonial a intensa aproximação às "domesticidades". A categoria "domesticidade" entra em cena articulada às relações de poder dentro e fora dos lares. Conceituada como "experiência de intimidade que se diversifica em função do posicionamento social das pessoas [...] e articulada às noções de cuidado, à circulação de afetos, de emoções" (PISCITELLI, 2016, p. 49), a domesticidade é característica marcante do trabalho do cuidado. Ela independe de remuneração; sua força ideológica e moral encontra-se na persistência da lógica patriarcal e suas relações de poder. Nesse sentido, podemos afirmar que ela não só está articulada, como é extremamente necessária à reprodução do trabalho do cuidado e à precarização da força de trabalho feminina, principalmente da mulher negra, historicamente inserida nas relações precarizadas e subalternas de trabalho.

Embora a inserção da mulher negra no mercado de trabalho tenha sofrido mudanças nos últimos trinta anos, com a efetivação de um conjunto de políticas públicas, em especial as de renda e de educação, grande parte das mulheres negras ainda se encontra inserida no setor de serviços. Os estudos sobre desigualdades de gênero e raça no Brasil, realizados pelo Instituto de Pesquisa Econômica Aplicada em 2017, nos auxiliam na compreensão das relações de consubstancialidades no mercado de trabalho na atualidade. Segundo os mesmos, a taxa de participação da população feminina em idade ativa (de 16 a 59 anos) trabalhando ou à procura de emprego, no período de 1995 a 2015, oscilou entre 54\% e 55\%, não tendo jamais chegado a $60 \%$. Isto significa que quase a metade das brasileiras em idade ativa não está inserida no mercado de trabalho e nem à procura de trabalho. São mulheres que assumem os trabalhos domésticos e de cuidado da família, tratados, tradicionalmente, como funções femininas.

Outra explicação encontra-se na pouca escolaridade e na dificuldade de se inserirem no mercado de trabalho, como veremos mais adiante. Em 2015, a taxa de desocupação feminina era de $11,6 \%$ e, no caso das mulheres negras, de 13,3\%. Chama atenção a centralidade do emprego doméstico entre as ocupações femininas. No caso das mulheres negras, o emprego doméstico referese a $18 \%$ das ocupações. No entanto, apesar de constituírem o maior grupo entre as domésticas, ainda permanecem as desvantagens das trabalhadoras negras em relação às brancas no item formalização e proteção social. Enquanto $29,3 \%$ das trabalhadoras domésticas negras tinham carteira assinada em 2015, entre as brancas, esse índice chegava a 32,5\%. Segundo a PNAD contínua de 2016, o Brasil tinha 6.158 milhões de trabalhadores(as) domésticos(as), dos quais 92\% eram mulheres. Em 2015, 88,7\% dos(as) trabalhadores(as) domésticos(as) entre 10 e 17 anos eram meninas e 71\% eram negras. Segundo dados da Organização Internacional do Trabalho

\footnotetext{
As desigualdades de gênero e raça são eixos estruturantes da matriz ou do padrão de desigualdade social no Brasil, padrão esse que, como já foi assinalado, está na raiz da permanência e reprodução das situações de pobreza e exclusão social. As desigualdades e a discriminação de gênero e raça no Brasil são problemas que dizem respeito à maioria da população: as mulheres representam $42 \%$ da População Economicamente Ativa (PEA) no Brasil e os negros, de ambos os sexos, representam 45\%. Somados, correspondem a $68 \%$ da PEA, ou seja, 55 milhões de pessoas. As mulheres negras, por sua vez, correspondem a $18 \%$ da PEA, o que significa 14 milhões de pessoas e, como resultado da dupla discriminação de gênero e raça, apresentam uma situação de sistemática desvantagem em todos os indicadores sociais e de mercado de trabalho considerados (OIT/GRPE, 2016, p. 51).
} 
Cabe registrar a melhoria dos indicadores de escolaridade nos últimos 20 anos, em virtude dos Programas de Transferência de Renda condicionados à frequência escolar. Além disso, a expansão da rede púbica, das matrículas e do transporte escolar possibilitou a universalização do ensino fundamental no país, ainda que este seja objeto de crítica, diminuindo o tempo de estudo entre pobres e ricos. No entanto, ainda salta aos olhos a discrepância entre brancos e negros no que se refere ao grupo com maior escolaridade, $25,9 \%$ contra $12 \%$. Embora esse dado nos indique que os brancos com maior escolaridade representam o dobro dos negros em igual posição, ele nos revela, também, que a participação dos negros nesse grupo cresceu $300 \%$ nas duas últimas décadas. Certamente em razão das políticas públicas afirmativas que estabeleceram cotas raciais e sociais nas universidades públicas estaduais e federais. Outro dado favorável refere-se ao crescimento do percentual de negros com 9 a 11 anos de estudo, de $10,9 \%$ em 1995 para 29,2\% em 2015. Se observarmos com cuidado, esse percentual se iguala entre brancos e negros em 2015 (29,2\% e 29,3\%). Esses dados são de extrema importância para refletirmos sobre os impactos positivos das políticas públicas universais, neste caso, da Educação, aliada às políticas de recorte racial/cor.

As pesquisas sobre a implementação da política de cota racial em todo o território nacional têm apontado resultados bem positivos no que se refere à democratização do acesso à universidade, ainda que precisemos avançar na política de permanência dos jovens universitários, já que o índice de evasão deles vem crescendo e ameaçando o resultado da política de cota nos últimos dois anos. Todavia, no que tange à escolaridade das mulheres negras em idade adulta, os dados apontam o que a literatura já vinha chamando a atenção: o abandono precoce em virtude da necessidade de "ajudar na renda familiar", considerado o principal motivo para o abandono da escola nos anos de 1980 e 1990, já que esse público não contou com as políticas governamentais de permanência na escola, nem tampouco com os programas universais de combate ao trabalho infantil, que se generalizam como modalidade de política de assistência social no final dos anos de 1990, e se universalizam a partir dos anos de 2003. Entre as ocupações mais precarizadas, no que se refere à mulher negra, o trabalho doméstico traduz a vulnerabilidade social das mulheres negras e dos seus antepassados, inseridos em uma rotina circular de vidas subordinadas, na qual as avós foram domésticas, as mães foram domésticas e suas filhas têm grande probabilidade de serem domésticas. Essa "cadeia de subordinação" só pode ser quebrada pela via das políticas públicas que busquem equidade, igualdade e a eliminação das desigualdades sociorraciais e de gênero.

\subsection{A inserção da mulher negra no mercado de trabalho em Campos dos Goytacazes, sob a perspectiva da consubstancialidade (classe, gênero e raça).}

Tendo em vista recuperar, com base em uma análise consubstancial, o processo histórico de inserção da mulher negra no mercado de trabalho, destacando suas experiências com o racismo estrutural, serão utilizados tanto os dados quantitativos oriundos de fontes secundárias, como os relatos das entrevistas realizadas com cinco trabalhadoras negras de idades e gerações distintas. Os dados quanti-qualitativos serão analisados levando em consideração as diferentes fases da economia local, no pós-abolição, com base em autores como Cruz (1986, 1992, 2003), Benetti (1986) e Neves (1986, 1999, 2000, 2005).

De acordo com a produção teórica desses autores, podemos considerar três fases na economia local por meio da abolição da escravidão. A primeira fase tem início com o fim da força de trabalho escravo e a emergência do homem livre, e segue até os anos de 1950. A segunda fase tem início a partir dos anos de 1950 e vai até os anos de 1990. Ela inclui os processos de modernização técnica no campo e a expropriação de meeiros e colonos e, mais 
tarde, já nos anos de 1960, as mudanças nas relações de trabalho no meio rural e a intensificação das expropriações dos colonos e moradores que passam a residir na cidade e a trabalhar apenas durante as safras (seis meses). Essa situação permanece até o início dos anos de 1990, quando as usinas locais e da região entram em processo de falência, fechando as suas unidades e demitindo os poucos trabalhadores assalariados que ainda restavam nas unidades industriais e no campo. A terceira e última fase tem início nos anos de 1990, com a perda da centralidade do setor sucroalcooleiro na economia local e vai até os dias de hoje. Esta fase caracteriza-se não apenas pela diversificação das atividades econômicas, polarizadas agora pela produção e exploração do petróleo e gás na Bacia de Campos (CRUZ, 2003), mas, principalmente, pelo contexto aberto de possibilidades pela efetivação das políticas públicas, sobretudo aquelas relativas ao trabalho, à renda e à educação a partir de 2003. Além disso, esses marcos temporais são importantes tanto do ponto de vista da análise do mercado de trabalho e sua dinâmica, quanto da problematização das trajetórias e experiências de trabalho e racismo estrutural das mulheres negras, em uma perspectiva consubstancial e histórica.

Na primeira fase, encontram-se as relações mais próximas e de dependência entre os trabalhadores, ex-escravos, e os donos de terra. Estes primeiros trabalhadores assumiram a condição de moradores, colonos e meeiros, trabalhando e morando nas fazendas de cana-deaçúcar, e reféns de uma estrutura tradicional de poder. Essas características serão enfatizadas pela primeira entrevistada, uma mulher negra de 73 anos (E.), aposentada, cuja memória nos apresentou um conjunto de relações herdadas do período escravocrata, com a presença marcante do patriarcado e do racismo e pelas relações de trabalho degradantes e violentas, principalmente na infância. Na segunda fase, a expropriação do campo e a residência nas margens da cidade, sem qualquer proteção social, obrigava os trabalhadores e trabalhadoras rurais, agora na condição de "boias-frias", a buscarem novas atividades no mercado de trabalho urbano, durante o período da entressafra da cana. Essa demanda foi fundamental para a formação do mercado de trabalho urbano, fazendo com que o trabalhador rural se transformasse em uma força de trabalho para qualquer tipo de capital (BENETTI, 1986), reproduzindo na cidade condições muito semelhantes às do campo, sobretudo no que se refere às baixíssimas remunerações e à ausência dos vínculos formais de trabalho e de proteção social (CRUZ, 1986). Os relatos da segunda (R.) e da terceira (J.) entrevistadas, mulheres negras com idades de 60 e 54 anos, empregada doméstica e faxineira/diarista, respectivamente, demonstram as mudanças nas suas condições de vida e trabalho e, também, nas suas experiências no cenário urbano.

Marcado pelo forte desemprego no setor sucroalcooleiro, como já assinalado, a terceira fase caracteriza-se pela associação do período de declínio da cana com a diversificação da economia e do mercado de trabalho, embora permaneçam reservadas às mulheres negras as atividades relacionadas aos setores menos relevantes econômica e socialmente, como os serviços domésticos e as atividades do cuidado. Observa-se, ainda, o legado da escravidão, assim como da desigualdade de gênero no mercado de trabalho local, mesmo que as resistências às práticas sexistas e racistas estejam mais presentes. De outro lado, ganham efetividade e capilaridade as políticas públicas de igualdade racial, graças ao protagonismo dos movimentos negros do país. Espalham-se experiências denunciando o racismo estrutural e as relações patriarcais que penalizam, muitas vezes com a morte, as mulheres, especialmente as negras e, também, aquelas valorizando a identidade negra e o feminismo interseccional. Para auxiliar a problematizar essa fase, contaremos com as entrevistas de duas mulheres negras, uma de 31 anos (D.), técnica em química e graduanda em Serviço Social e a outra de 24 anos de idade (M.), assistente social e mestranda. Nas suas palavras, novas demandas, novos olhares e outras perspectivas. 
Na região Norte Fluminense, assim como em todo o Brasil, a mão de obra escrava negra se configurou como um fator impulsionador da acumulação e expansão do sistema précapitalista, fruto do trabalho compulsório aliado ao comércio de escravos e à exportação de produtos. Segundo Silva (2012, p. 5), “a escravidão além de base econômica da colonização brasileira foi também o fundamento de todas as esferas da vida social e política". O escravismo imprime a desigualdade e a exclusão como regras básicas do convívio social. A sociedade escravocrata estabeleceu o império da violência, pois o trabalho compulsório prescinde o da hegemonia. Neste sentido, ao analisar as relações de inserção do negro no mercado de trabalho no pós-abolição na sociedade campista, percebemos que a abolição não liberta o negro do preconceito de cor sofrido por ele diante da sociedade, mas vincula-se ao preconceito de cor, o preconceito de classe, conceitos como já foi dito estreitamente imbricados na constituição do Brasil e, principalmente, na região Norte Fluminense. Logo, Ribeiro (2012, p. 40) afirma que "a cor desempenha o papel de um símbolo, é o critério bem visível, que situa um indivíduo em certo degrau da escala social". Nesta mesma direção, Batisde e Fernandes (2008, p. 140) afirmam que "o preconceito de cor, cuja função era justificar o trabalho servil africano, vai servir agora para justificar uma sociedade de classes".

Assim, após a abolição da escravidão, negras e negros tiveram inicialmente como opção de subsistência o trabalho nas antigas atividades, nas terras dos antigos senhores como trabalhadores livres. Esse tipo de relação na cidade de Campos dos Goytacazes perdurou até meados do século XX. As relações imediatas no pós-abolição seguem basicamente em duas direções. Segundo Neves,

\begin{abstract}
Se para a primeira e segunda geração o trabalho infantil era algo totalmente naturalizado na sociedade com tipos particulares de inserção da mulher negra no mercado de trabalho, como expressada na fala de uma das entrevistadas como "pegava pra criar", denotando uma utilização da força de trabalho infantil com consentimento por parte dos responsáveis, isto não acontece no caso das três últimas gerações. A transmissão intergeracional da posição precária adquire maior expressividade no caso das famílias que se valem do trabalho remunerado (direta ou indiretamente) dos filhos durante a infância. Estes, desde tenra idade, devem internalizar os limites sociais como modo natural de estar no mundo. São excluídos do acesso a alternativas de mudança de posição, porque integram poucas chances de conhecer outras formas de inserção social. Pelo contrário, acumulam as desvantagens da desqualificação, quando não são precocemente inviabilizados como portadores de força de trabalho mercantil, diante de acidentes e doenças profissionais e, da mesma forma, precocemente convertidos em deficientes e indigentes. $\mathrm{O}$ termo trabalho infantil tem sido considerado símbolo do irreconhecimento de determinadas atividades produtivas remuneradas, realizadas sob condições vis ou penosas por crianças e adolescentes, por isso mesmo interditado pela legislação. Tais condições são qualificadas como impeditivas da continuidade do processo de formação do ser adulto que então se encontra em curso, formação que abrange a complementação do ciclo de desenvolvimento físico, social, moral e profissional (2000, p. 151).
\end{abstract}

A continuidade da incorporação dos libertos em antigas atividades desempenhadas por eles em troca de moradia e outros meios de reprodução, expressa as raízes das formas consubstanciais de exploração. Neves (1986) afirma que quando o vínculo de trabalho pressupunha a agregação do morador na fazenda, este direito era garantia de inserção futura dos filhos como assalariados. Como podemos observar nos relatos, a primeira fase representa o ciclo de fundamentação das desigualdades de raça, gênero e classe com base nas novas relações capitalistas de produção. O trabalho feminino negro inserido nas relações de trabalho durante 
a primeira metade do século XX tem como maior característica a perpetuação das atividades laborais de seus antepassados.

Comecei com 8 anos. "O primeiro trabalho foi numa... eu lembro a casa... não fui muito bem-sucedida, que... é, eu era muito maltratada, né? A família era família de fazendeiros, brancos, entendeu? Meu avô foi escravo. Lá nesse lugar mesmo, no Zurá. Me lembro... meu avô Júlio Neto. Eu ia muito lá pra visitá na época de jovenzinha, né? Aí eu chamava minhas primas: vamos lá vê vovô, pra gente conversar, né? Aí eles perguntavam: e o senhor apanhava, vovô? Ele respondia que não. (risos) Aí uma olhava pra cara da outra, né? Havia muito respeito na época. Aí depois, quando chegava no meio do caminho, nós falava: será que vovô não apanhava mesmo, não? (risos) Minha vó era, era escrava também. Porque a gente queria saber como é que eles casou. Aí ele falou: comé que foi, que no engenho, que ele tava lá trabalhando, que ele olhava assim que dava a impressão que tinha alguém olhando pra ele, porque minha vó era cabocla, entendeu? Era arisca. Desse jeito. Aí, o dono do meu avô, eles faleceram, mas deixaram meu avô morando lá naquele lugar. Pôde continuar morando, os filho também construíram tudo lá. Os filho dele ficaram tudo morando lá nessa fazenda. Entendeu? Aí, de vez em quando a gente ia lá, vê a casa, meu avô. Não tinha cama. Era pilão, só via aquela coisa de madeira. Era casa de assoalho assim... mas era não tão chique igual a essa (se referindo ao prédio em que estávamos), mas a casa era de madeira, a casa da minha tia lá num era de telha, era de palha. Entendeu? (E., 73 anos, aposentada).

Nascida em 1945, a entrevistada E., com 73 anos no momento da entrevista, vivenciou juntamente com sua família o processo mais intenso de expropriação do campo de Campos. A entrevistada E. é a única que relata abusos sexuais e outras formas de violência decorrentes das suas relações de trabalho na infância. No que se refere à violência sexual, a entrevistada relata que seu primeiro serviço em casa de "família" foi uma experiência traumática: "Era horrível. Muito, muito triste, eu não gosto... essa parte aí, eu não gosto nem de lembrar, não, porque... é...” (E., 73 anos, aposentada).

A dificuldade em expor as memórias marcadas pelas suas primeiras relações de trabalho ainda criança nos leva a pensar o quanto o mercado de trabalho local foi forjado sobre o machismo, racismo e patriarcado. Seguimos a entrevista no objetivo de romper o silêncio.

Já, haram, essa mesmo (se referindo à primeira casa em que trabalhou). Ele era casado, acho que ele podia ser até meu pai, entendeu? Era casado. Eu, uma criança, e além do mais não foi só ele. Ele tinha mais filhos, e além do mais, não era só ele, os outros também eram casados, entendeu? Tinha dois irmãos que... um morava perto, que era vizinho dele mesmo. E outro morava na roça, de vez enquanto ia pra lá. Aparecia lá (E., 73 anos, aposentada).

Assim, percebemos que no que se refere à mulher negra, existiu uma relação estreita entre trabalho e servidão. As práticas escravistas não se resumiam somente nas relações de trabalho ou ao enquadramento dela como mucama. As relações que ora se desenvolviam envolviam profundo sentimento de posse e de poder com relação ao corpo e suas experiências. Como reflexo, tais vivências formavam mulheres extremamente submissas e traumatizadas.

Exatamente, haram [...] eu fiquei traumatizada e... não confiava em ninguém. Exatamente, quer dizer, isso tudo ficava na minha mente, mas você não podia se expressá. Cê tinha que aceitar o preconceito, aceitar a maneira deles tratarem, entendeu? Eu via sempre que elas colocava sempre as pessoas de castigo. O negro tinha mais. Entendeu? Eu era tão revoltada na época que, eu ficava assim. Se me chamar de negra... assim eu vou passar a andar com uma faca, uma gilete, eu vou 
cortar o braço dela e vou cortar o meu pra ver nosso sangue correr junto. Eu ficava assim, tanto revoltado, sabe? (E., 73 anos, aposentada).

A entrevistada relata que além do sofrimento e da precarização das condições de trabalho, ela era vítima dos abusos dos filhos dos patrões. A história do Brasil é marcada pelos traços sociais de violência contra a mulher. A comunidade patriarcal introduzida pela colonização no Brasil contribuiu para a construção de uma sociedade pautada na desigualdade e na exploração, no sexismo e na discriminação racial. Assim, outra característica presente na inserção da mão de obra feminina em Campos foi o assalto à infância. Segundo Neves, (1999), inseridas nas relações degradantes de trabalho na primeira metade do século XX na cidade de Campos, inicialmente no corte de cana e posteriormente nas atividades de serviços, como o trabalho doméstico,

As crianças, como os adultos, sobrevivendo a partir do constrangimento perversamente constitutivos desta atividade produtiva, respondem com mortificação exemplar do funcionamento adequado do corpo e dos sonhos (1999, p. 108).

Inserida no mercado de trabalho aos oito anos de idade, E. relata que "botava um caixotinho para fazer café... cozinhar...". Os atentados contra a sua inocência não foram capazes de retirar a sua pureza de criança. Isto fica explícito quando a entrevistada E. relata uma de suas memórias nessa casa,

\begin{abstract}
Ah, sim. É, essa pessoa mesmo ela me batia, muito. De vez enquanto, eu conto, né, pras pessoas, que a gente tem que falar a verdade, né? Aí, ela e o marido dela vinha da fazenda, trazia laranja, então ela botava ali pra vender. Chegou uma determinada pessoa, acho que era pra cobrar ela, no caso, né? Aí, ela falou: ó, diz que eu não estou. Eu na minha inocência, cheguei lá e falei assim: olha, ela mandou dizer que não tá. Aí a pessoa falou: ela o quê? Ela mandou dizer que não tá. Tá bom, e a pessoa pegou, foi embora. Quando eu entro, ela estava atrás da porta com o espanador. Menina, ela tocou o espanador na minha cabeça, que o outro pedaço voou longe. Quebrou o espanador na minha cabeça. Aí, eu comecei a chorar, porque doeu, né, na cabeça. Aí ela gritou: - Sua burra! Eu chorando e respondendo: - Mas a senhora num mandou dizer que a senhora não estava? Eu falei pra ele, que a senhora mandou dizer que não tá (E., 73 anos, aposentada).
\end{abstract}

É ela, também, a única que relata não ter se casado por amor, e sim por necessidade.

Eu casei por necessidade, pra ter um lar e também pra ajudar minha irmã que vivia arranjando filho e vivia pra baixo e pra cima, sabe?... não tinha paradeiro. Aí, eu casei também por isso, por necessidade. Pra... pra ter um lar. Hoje é bem diferente. Hoje você consegue um lar fácil, qualquer um. Na minha época, não. Era difícil, entendeu? Porque o salário era muito pequenininho, pagar aluguel, mas... hoje tá mais fácil. As pessoas reclamam. Mas, tá passando por um problema? Vai lá no centro de assistência social, procura um apoio, ajeita, paga um aluguel social, tudo isso (E., 73 anos, aposentada).

A entrevistada mais velha é também a primeira a relatar com clareza a perpetuação do racismo, com base em sua experiência de vida: "Eu falo assim: a escravidão não acabou. Ela amenizou, tá de forma diferente. Porque agora você não vai pro tronco, mas você é castigada na sua própria casa" (E., 73 anos, aposentada). No que se refere à escolaridade, E. afirma que, 
Bem pouco. Estudei pouco. Mas esse pouco que eu estudei, eu consegui fazer até um curso de enfermagem... e passei. E, na minha época, pra trabalhar de enfermagem, não precisava de você ter faculdade... nada disso. Bastava você demonstrar amor ao próximo. Hoje não, né? Hoje, cê faz faculdade... precisa porção de coisa. E disso mais o dinheiro. [...] negro...você não podia nem estudar. Podia não. Eu trabalhava de dia e estudava a noite. Eu estudava à noite no Auxiliadora. Colégio Auxiliadora. [... ] Só que num aceitava ser freira. Porque eu queria ser... na época, num era freira, não. Queria ser filha de Maria. Não podia por causa da minha cor. As freiras tinham preconceito. É... até as freira. Até as freira (E., 73 anos, aposentada).

Segundo Reis,

Nesse contexto surgem referências, tanto familiares quanto não familiares, que contribuem para afirmação das identidades raciais negras. Pois sabemos que a afirmação do ser humano é um fenômeno que se constrói através das relações sociais. É o contexto sociocultural (família, rua, bairro, livro didático, meios de comunicação de massa) o responsável pelo processo identitário (2017, p. 62).

Logo, estar na escola não significava em nenhum momento sentir-se pertencente àquele lugar. Neste sentido, faz-se necessária a busca por uma práxis pedagógica que tenha como perspectiva a constante revisão dos seus conteúdos e práticas. Para Candau,

Os veículos de discriminação vão desde o currículo formal, que exclui múltiplas e variadas maneiras de expressão cultural, passando pela linguagem não verbal, até chegarem, frequentemente, ao nível dos comportamentos e das práticas explícitas (2003, p. 24).

Perguntei a ela como era ser negra em um colégio de alunos majoritariamente brancos e onde se cultuava um Jesus também branco.

É, né, nem... nem imaginava, assim não. Eu via Jesus como uma pessoa loira, dos cabelo cacheado, né? Anjos de cabelo cacheado, tudo branco, nada preto, porque era o que aparece nas festa, né? Aí, tinha dia que aparecia as meninas vestidas de anjo, era tudo branquinha, bem clarinha. É ruim que negro... negro era considerado demônio. Só branco, loirinho, olhos azuis, aquela coisinha, sabe? E os negros tavam ali só pra aplaudir (E., 73 anos, aposentada).

É importante dizer que a mão de obra escrava liberta não se desvincula totalmente das antigas relações. A impossibilidade dos negros de adquirir terras no pós-abolição fez com que uma grande parcela continuasse nas terras do seu antigo senhor. Assim, os antigos escravos tornaram-se os trabalhadores dos engenhos e os trabalhadores dos engenhos tornaram-se lavradores e operários das fazendas e empresas de álcool e açúcar.

O trabalho no corte de cana acompanhando os pais e, depois, o trabalho doméstico, foi o caminho comum das crianças empobrecidas e majoritariamente negras na primeira metade do século XX. No caso da mulher negra campista inserida no mercado de trabalho, percebemos que há uma continuidade com as atividades do cuidado. Dentre outras atividades, o emprego doméstico foi a grande marca nas relações de trabalho feminino negro na cidade de Campos dos Goytacazes/RJ.

Cabe destacar que nesse período os trabalhadores trabalhavam na roça, mas já moravam na cidade, ponderavam o trabalho na cana com o emprego doméstico na cidade. O trabalhador rural em Campos dos Goytacazes passou a ser trabalhador braçal, doméstica, ajudante de 
pedreiro. Resta também se inserir nas novas configurações de trabalho, no pagamento feito "por produção ou tarefa".

Expulsando os trabalhadores da fazenda e muitas vezes financiando a vinda deles para os barracos nas favelas da periferia da cidade, aqueles empregadores viabilizaram também a transferência do papel de provedor para os empreiteiros, que precariamente, reproduzem o sistema de imobilização pela troca de favores, ampliada pelo maior aviltamento do valor da força de trabalho. Os trabalhadores clandestinos, ainda que muitas vezes proprietários dos seus barracos ou vivendo em casebres concedidos pelos empreiteiros, reproduzem nas favelas uma miríade de relações viabilizadoras da constituição dos modos de dominação personalizados com os diversos concorrentes intermediários do seu recrutamento. Com salários cada vez mais rebaixados e inconstantes, os trabalhadores criam relações de agregação com os empreiteiros que lhes concedem a honra de crédito e um processo incessante de endividamento assegurador da reprodução física deles mesmos e de seus familiares (NEVES, 1999, p. 123).

Vejamos os relatos de uma das trabalhadoras do segundo ciclo.

Meu primeiro serviço que foi cortar cana. Trabalho desde idade de 12 anos. Trabalho em casa de família. Tô com 60 anos, fiz esse ano. Desde idade de 12 anos. A casa era ... morava lá no Turf. Fui nascida e criada lá no Turf. Já ouviu falar na Antônio Manuel, atrás do Asilo? Então, fui nascida e criada ali. Primeiro, comecei que, a cortar cana. Cortei cana e tudo. Antônio Manuel era só cana. Ía com o pessoal, mesmo. Eu tinha o quê? Uns 12 anos mais ou menos. Aí parei. Fui pra casa de família, lá perto onde eu morava mesmo, lá na Antônio Manuel (R., 60 anos, empregada doméstica).

Ela foi a única que rejeitou a ideia de ser mulher negra e direcionou sua fala na articulação direta entre cor e criminalidade.

Pá dizer a você, não, vou dizer a você que eu não sou, porque eu sou, mas a gente nunca considera, né, que a gente seja, né? Até... porque... quero dizer... às vez, a gente vai num lugar, num mercado, numa loja para comprar alguma coisa, aí fica assim, as pessoas que trabalha ali, né, olhando a pessoa, por causa da cor da gente, né, “siminina”, tá... É nega, né, olhando pra pessoa, olhando com aquele olhar achando que a pessoa vai até... mexer em alguma coisa, né? Tem gente que critica a gente até pra tudo, né? Pra trabalho, né? (R., 60 anos, empregada doméstica).

Então, levanta-se uma importante reflexão. Nascida em 1958 e inserida no mercado de trabalho em 1970, já que ela relata que começou a trabalhar com doze anos, a primeira entrevistada do segundo ciclo teve grande parte da sua vida ativa inserida nas relações provenientes da ditadura militar, período da história do Brasil em que a população negra sofreu mais uma vez a atroz fome de poder e impiedade da classe média branca. Segundo Jesus (2016), o período da ditadura militar foi o período de consolidação e negação de qualquer contestação do mito da Democracia Racial. Desta forma, pensar na questão racial ou reivindicar questões negras naquele período estava diretamente ligada à subversão da ordem vigente, por isso, era melhor não ser negro, não se ver enquanto negro e não sofrer possíveis retaliações. Quando pensamos a resposta da entrevistada como reflexo da construção de suas relações de vida baseadas principalmente no período de sua infância e adolescência, percebemos o quanto o período da ditadura e as relações de coerção advindas desse período podem ter limitado a apropriação e construção de uma identidade negra livre.

Tal perspectiva nos leva a pensar que a apartação do contingente feminino negro dos espaços de educação gera um movimento contínuo da sua autorrejeição, sua autoidentificação, 
ou seu autorretrato, como salienta Collins (2019), face à ausência da valorização de suas características identitárias e da dificuldade de acesso aos bens e serviços na sociedade, reproduzindo os campos de exclusão. Da mesma forma, chamamos a atenção para o papel da escola e do ambiente escolar enquanto espaço privilegiado de enfrentamento das múltiplas formas de desigualdade e discriminação detidos em um trabalho pedagógico voltado para uma pedagogia libertadora e de uma escola voltada à reprodução das práticas racistas e machistas vigentes na sociedade.

Tal processo, visto por meio do olhar da consubstancialidade, apresenta uma nova perspectiva de análise sobre o processo de constituição do mercado de trabalho na cidade de Campos. Segundo Benetti,

A "escassez" determina a incorporação de mulheres e crianças, assim como há, também, a importação de trabalhadores de outros estados. [...] a incorporação de mulheres e crianças no corte de cana não teria outra explicação senão a "escassez" de mão de obra na safra (1986, p. 60).

Tal processo, ao inserir a criança nas relações de trabalho degradantes e de forma precoce, ao mesmo tempo a apartava das possibilidades de estudo. A dificuldade de conciliar trabalho e estudo gerou condições específicas de manutenção da atividade de cuidado no tocante a consubstancialidade do mercado de trabalho nas primeiras décadas do século XX. A remuneração do trabalho infantil era pago ao seu pai ou a outro responsável direto. A relação de trabalho era uma relação de agregada e empregada. A remuneração do trabalho infantil tornavase uma perfeita fonte de renda ao se despender das despesas da criança e receber pelo seu trabalho na casa de outrem. A criança negra e pobre submetida às relações de trabalho era uma espécie de força de trabalho alugada por tempo indeterminado.

O termo "pegar pra criar" era costumeiramente utilizado para respaldar a exploração da mão de obra infantil das famílias pobres e de grande prole. Era comum, segundo as entrevistadas, que os pais deixassem suas filhas serem criadas por famílias com maior poder aquisitivo.

Sem mãe. Minha mãe faleceu eu fiquei com 5 anos. Aí fiquei com meu pai. Ficava
um tempo na casa de um, um na casa de tia, até pegar uma idadezinha coisa, né? Aí
minha, eu morava com meu pai, com meus irmão, que minha mãe deixou 4 filhos, e aí
veio essa família, pediu pra criar, só que criar era desse jeito. Naquela época, os pais
acreditavam nos adultos, não nos filhos, é nas pessoas, né? (E., 73 anos, aposentada).

Após a década 1960, os trabalhadores e trabalhadoras rurais desvinculados(as) de sua atividade e reinseridos no meio urbano sem infraestrutura e sem nenhum tipo de proteção social, configuram a parcela de maior vulnerabilidade social.

Sendo assim, entre incertezas e o desafio da sobrevivência, as mãos dos trabalhadores que outrora concretizavam a magia da terra, tiveram que aprender novos ofícios. Expropria-se o trabalhador, desvaloriza sua força de trabalho, sua vida, lhe nega direitos e dignidade. Fazse assim a manutenção do exército de reserva/sobrantes em Campos dos Goytacazes. A única certeza, no entanto, é a da pobreza e da precariedade das condições de vida na cidade para esses trabalhadores (CRUZ, 1992). O trabalhador rural em Campos passou a ser trabalhador braçal, doméstica, ajudante de pedreiro. Com base nos relatos da segunda entrevistada do segundo ciclo, a versatilidade dessa mão de obra na cidade se evidencia. Assim, nessa segunda fase, em que a urbanização toma corpo, os trabalhadores expropriados de seus antigos labores tornam-se na cidade "mão de obra para qualquer capital" (BENETTI, 1986). 


\begin{abstract}
Minha mãe ela lavava roupa pra fora, ela... qui! Qualquer tipo de serviço que tinha, ela tava pegando, ela tava fazendo. Ela lavava roupa pra fora, ela cozinhava pros outros, trabalhava fora, era cozinheira, trabalhou muitas vezes na roça. Então é daquele tipo de pessoa que trabalhava e ensinou a gente a trabalhar. E se fizesse de qualquer jeito, ela mandava fazer de novo até fazer do jeito dela. E o que eu sei fazer até hoje, eu agradeço a ela. [...]. Então papai como era carpinteiro, marceneiro, pedreiro, a gente, eu e minha irmã mais velha, todo ano, nós comprava um presente de natal pra gente, que papai mandava (J., 54 anos, faxineira/diarista).
\end{abstract}

"O conceito de mobilidade supõe colocar em destaque a versatilidade da força de trabalho na sua imensa capacidade de transformar-se frente aos ditames do capital" (BENETTI, 1986, p. 50). Essa versatilidade é uma das características do segundo ciclo produtivo da região Norte Fluminense e que se torna mais latente nas relações de trabalho a partir das décadas de 1970-1980, na cidade de Campos dos Goytacazes/RJ.

É importante ressaltar que os problemas referentes à urbanização campista começam a emergir após a crise do açúcar nas décadas de 1940 e, segundo Faria (2005), mais especificamente nas décadas de 1950-1960, quando intensifica a dualidade centro-periferia e o meio urbano recebe um número grande de trabalhadores rurais, totalmente desencaixados desse novo contexto e das novas relações de trabalho. Era comum falta de saneamento básico, água potável, transportes coletivos, entre outras ausências de mecanismos básicos para a reprodução da força de trabalho.

Segundo Faria (2005), é na década de 1980, devido à somatória de vários fatores, dentre eles a falência das usinas de açúcar, o inchaço urbano oriundo da falta de trabalho no campo e a precarização do mercado de trabalho na cidade, que a favelização torna-se uma grande problemática para a cidade. Nesse sentido, a autora afirma que

A lógica de desenvolvimento urbano campista não acompanhou seus desdobramentos sócio espaciais, em razão, sobretudo, da concentração demográfica urbana em expansão e da paralela falta de estrutura da cidade (2005, p. 47).

A urbanização do mercado do trabalho, segundo Cruz (1992), da forma que se deu em Campos dos Goytacazes, introduz o trabalhador em um universo de instabilidade, insegurança e desamparo. O segundo ciclo se inicia entre os anos 1950 e 1990, entre 1970 e 1991 a população urbana de Campos/RJ cresceu 89,19\%, enquanto a população rural diminuiu 51,59\%.

Em aproximadamente vinte anos, a cidade é totalmente redesenhada em função das novas relações de trabalho. Ainda segundo Cruz (1992), a cidade torna-se receptora da população do interior do município e de outros municípios da região, uma etapa "intermediária" na migração para centros maiores. Logo, as novas determinações do trabalho no corte de cana, influenciado pelo Estatuto do Trabalhador Rural de 1963, assim como o enquadramento do trabalhador rural de usina como industriário (para enquadramento na CLT), e as novas formas de contratação desses trabalhadores, por intermédio das firmas empreiteiras, comumente chamadas de "gatis", ocasionam em grande escala a inserção da força de trabalho feminino no trabalho doméstico.

Segundo Neves, "o cancelamento das atividades de algumas usinas representou maior empobrecimento para os trabalhadores a elas vinculados; repercutiu na reordenação dos modos de utilização da força de trabalho diante do rebaixamento dos salários" (1999, p. 118).

É esse processo também que aloca a cidade de Campos como Centro de Comércio e Serviços (CCS). Segundo Cruz (1992), o ponto fulcral da constituição do mercado de 
trabalho em Campos se dá entre as décadas de 1960 e 1970, por meio de mudanças técnicas no campo, mudanças das relações de trabalho por meio das novas exigências legais para vínculos empregatícios de trabalhadores rurais, Estatuto do Trabalhador Rural de 1963, assim como o enquadramento do trabalhador rural de usina como industriário (para enquadramento na CLT), e as novas formas de organização neoliberais, como as firmas empreiteiras. Tal processo, situado no segundo ciclo de exclusão consubstancial, fortemente marcado na década de 1970,

Nova intensidade do processo é objetivada na década de 70 , diante do aumento da mecanização das atividades agrícolas e do deslocamento das famílias do interior das fazendas para a periferia da cidade. O processo de migração no momento é menos intenso e mais caracterizado pelo vaivém de trabalhadores minimizando os efeitos do fechamento do mercado de trabalho em Campos dos Goytacazes (NEVES, 1999, p. 126-127).

Todo esse processo leva à profunda desvalorização da mão de obra dos antigos trabalhadores rurais, gerando assim relações de subemprego, desemprego, informalidade e marginalidade. Neste mesmo sentido, outros fatores levaram ao enfraquecimento das antigas relações de trabalho nas usinas. A lei 4.870 de 1965, que preconizava assistência médica, hospitalar, farmacêutica e social aos trabalhadores das usinas, financiada por meio de recursos das porcentagens sobre o preço e valor dos produtos das usinas, representou um marco para o Instituto do Açúcar e Álcool (IAA). Embora os recursos tenham servido para outros fins.

Sendo assim, concordamos com Cruz, quando infere a hipótese de que

Existiria no Norte Fluminense, por parte do grande capital agroindustrial e seus aliados da lavoura e da cidade, uma estratégia de produção e reprodução permanente da situação de penúria, abandono, esvaziamento, estagnação e ausência de alternativa, como suporte para a manutenção das condições de exploração da força de trabalho necessária à forma como a acumulação se dá atualmente na região (1986, p. 41).

Ainda segundo Cruz, dois aspectos chamam a atenção no bojo analítico da formação do mercado de trabalho campista no segundo ciclo: “a) O contingente feminino e infanto-juvenil é um componente fundamental de força de trabalho em decorrência de se tornar o principal meio de aumentar o ganho do trabalho; b) o mercado de trabalho em Campos se sustenta no trabalho informal" (1992, p. 30), seja no corte de cana, seja no meio urbano, a presença da mulher no mercado de trabalho é marcante, tendo no pós-64, em média, $20 \%$ das residências chefiadas por mulheres, com o trabalho no corte de cana representando a segunda ocupação das trabalhadoras.

Na década de 1990, a maior parcela da população economicamente ativa estava no setor de serviços e, em segundo lugar, na construção civil. No setor de serviços, destacamos a atividade do serviço doméstico. Segundo estudos de Cruz (1992), nos anos 1990, a produção de cana e açúcar por usinas altamente tecnificadas passou a ser metade daquela dos anos 1980, fazendo com que o emprego no setor, entre meados de 1980 e 2001, diminuísse de cerca de 50 mil para aproximadamente 15 mil. A perda de 35 mil postos de trabalho deslocou esse mesmo tanto de mão de obra para o mercado de trabalho urbano. Em uma análise referente às duas décadas que seguiram os anos 1990, percebemos que o setor de serviços continua empregando a maior parcela da população Norte Fluminense.

De acordo com a pesquisa realizada com os beneficiários do Programa Bolsa Família (PBF) de Campos dos Goytacazes, segundo Almeida (2012), o trabalho na cana de açúcar atingia apenas $4,1 \%$ dos trabalhadores, bem atrás das ocupações urbanas, como pedreiro e ajudante de pedreiro (17,6\%), faxineiro(a)/diarista (14\%) e servente/auxiliar de serviços gerais $(7,5 \%)$. Se 
considerarmos o recorte de gênero e trabalho, observaremos que segundo o IBGE (2011), os setores de serviços e de comércio continuam como os principais empregadores da força de trabalho feminina em Campos dos Goytacazes. Ainda segundo o IBGE (2011), a população feminina economicamente ativa era de 87.178 pessoas. Dentre elas 44.179 mil, ou seja, 51\% eram mulheres pretas e pardas e $91 \%$ do total das mulheres com mais de 16 anos de idade estavam alocadas no setor de serviços. A taxa de ocupação das mulheres brancas com mais de 16 anos de idade era de $51,18 \%$ contra $49 \%$ das mulheres negras. Ao observarmos os microdados do Censo 2010 , referentes à escolaridade com base no gênero, percebemos que apenas 34\% das mulheres ocupadas têm ensino médio completo ou superior incompleto. As mulheres sem instrução ou com ensino fundamental incompleto formam o segundo grupo de ocupação feminina, com $30 \%$, reproduzindo o quadro nacional em relação à escolaridade. No que se refere ao grupo com pouca ou nenhuma escolaridade (quase 1/3 das trabalhadoras), supomos que esse seja o grupo que ocupa as atividades precarizadas e subalternas como o serviço doméstico, a faxina, dentre outros. No ano de 2015, cerca de 5.755.600 mulheres estavam ocupadas no trabalho doméstico no Brasil, divididas em 2.008.289 de mulheres brancas e 3.747.311 de mulheres negras. Na região Sudeste, que concentra a maior parcela de todas as regiões, com 2.667.919 mulheres no emprego doméstico, tínhamos 1.005.711 de mulheres brancas em ocupações domésticas, enquanto o número de mulheres negras era de 1.662.208.

As entrevistadas mais jovens, D. de 31 anos, Técnica em Química, trabalhadora de uma empresa local e estudante dos últimos períodos de Serviço Social e M. de 24 anos, Assistente Social e mestranda, fazem parte do conjunto de elementos que formam a análise da terceira fase, como já anunciado. Essas mulheres vivenciaram experiências novas por meio do acesso às políticas públicas e dos sistemas de proteção social criados com base na Constituição Cidadã. Embora suas ancestrais não tenham tido acesso às mesmas oportunidades e direitos reconhecidos, suas histórias de luta, renúncia e resistência são o ponto de partida dos relatos das nossas jovens. Embora essas jovens tenham desfrutado da existência de políticas públicas educacionais, trabalho e renda, proteção e promoção da dignidade humana e equidade racial, ambas sofreram pelo machismo, sexismo e racismo em seus contextos de trabalho.

Isto se confirma no relato da entrevistada D. de 31 anos:

E esse negócio de... voltando um pouquinho, que eu lembrei de uma coisa que é superimportante, que dói no meu bolso, essa questão dessa desvalorização. Tipo assim, nessa função que eu tô, os homens, nem todos, mas a maioria deles ganha muito mais do que eu tendo a mesma ocupação - eu acho isso um absurdo! Sim, é um absurdo isso! Não por achar, entendeu? Por ter essa coisa lá. É bem forte essa coisa lá, de que o serviço dele, o que ele tá fazendo, é mais importante pra empresa do que o que ela tá fazendo... Porque como, tipo assim, por mais que o meu serviço perpasse o serviço de todo mundo lá dentro, eles olha, acho, que como o final, que é um homem que vai lá e toca e finalizou, entendeu? (D., 31 anos, Técnica em Química, trabalhadora e estudante dos últimos períodos de Serviço Social.)

O racismo se evidencia no relato da entrevistada, por meio da forma com que a sua patroa a obrigava a usar seu cabelo, e foi apenas após se inserir nos movimentos sociais de luta negra que ela se deu conta da sutileza do racismo sofrido.

\footnotetext{
$\mathrm{Na}$ época, provavelmente achava mesmo né, porque eu prendia rabo (rabo de cavalo) e eu tenho a frente do cabelo um pouco mais lisa, meu cabelo não é crespo desde o início, é mais liso... Eu prendia o cabelo sempre de rabo e aí, eu só me dei conta aqui e aí, eu falei "Cara, não é um processo explícito, violento assim”, mas é uma "violência" no sentido de interferir na minha imagem né, de qual é a imagem do belo,
} 
porque eu não podia ser uma menina negra com o cabelo cacheado que eu sempre tive, nunca alisei, cacheado solto, porque isso agredia o padrão de estética que ela (dona) tinha para as vendedoras da loja e que não era só das vendedoras da loja, era para clientela dela, que eram todas mulheres brancas de classe média alta. E eu só consegui fazer esse link (conexão) depois que a Paloma falou isso comigo e eu fiquei pensando "Caramba, a J... também é negra com o tom de pele mais claro, assim como eu, e sempre teve cabelo alisado e eu nunca a vi falar nada". A Jéssica sempre usou cabelo alisado, solto, a E. eu levei pra lá também, é uma menina branca, de cabelo liso e ela nunca falou nada. Aí eu só consegui me ligar nisso aqui, agora... (M., 24 anos, Assistente Social e mestranda em Planejamento Urbano e Regional).

Sendo assim, formular políticas públicas que considerem as especificidades de vida das mulheres negras, torna-se um esforço de perceber que enquanto estivermos formulando políticas estanques, que focalizam em uma ou outra problemática, será impossível alcançar os almejos de uma sociedade mais justa, igualitária e antirracista. Quebrar as cadeias de subordinação (CRENSHAW, 1989) exige um esforço para compreender e agir sobre as políticas de forma que se articule a educação no sentido de acesso e permanência, articuladas com outras políticas, como a de trabalho e renda, com apoio tanto na inserção digna e em idade certa no mercado de trabalho, quanto por meio de métodos de permanência e proteção às leis do trabalho, proteção social com base nas políticas de assistência social e ações afirmativas voltadas para o fim do racismo, fortalecimento das identidades, ampliação das cotas nas universidades e o espraiamento dessa política a outros espaços, focalizando nas mulheres, crianças e adolescentes negras, tendo em vista suas especificidades.

\section{CONSIDERAÇÕES FINAIS}

$\mathrm{O}$ acesso às políticas públicas, principalmente as de redistribuição de renda e de igualdade racial são fundamentais para que as mulheres negras ultrapassem as barreiras postas pelo racismo estrutural, pela desigualdade de classe, pelo machismo e sexismo. Os resultados da pesquisa deixam claro que o acesso aos níveis de escolaridade mais elevados, como a educação superior, por exemplo, não é garantia de uma inserção qualificada no mercado de trabalho. Nesse sentido, ainda são inúmeros os desafios e nos parece que as políticas públicas voltadas ao combate à pobreza e à geração de emprego ainda são bastante tímidas diante dos desafios, sobretudo por meio do revés que o país vem enfrentando desde 2016 e, atualmente, com a eleição de um governo ultraneoliberal e de viés conservador, sem nenhum compromisso político com os direitos sociais e com as políticas de combate ao racismo estrutural. Pelo contrário, suas manifestações durante a campanha eleitoral e nesses 18 meses de governo, já demonstraram a natureza patriarcal, haja vista as nomeações de militares e pastores em ministérios importantes, como o da saúde e o da educação. Nesse sentido, três questões ainda permanecem nos desafiando. A primeira diz respeito à incorporação de uma dimensão de gênero e raça nos métodos de medição da pobreza, como forma de visibilizar as particularidades das mulheres negras. Se a pobreza é heterogênea e consubstancial, essa realidade deve ser apresentada também nos indicadores. A segunda refere-se ao acolhimento das pautas dos movimentos sociais às agendas públicas governamentais, estabelecendo novos caminhos para formulação de políticas públicas coerentes. E a terceira está relacionada ao desafio coletivo de gerar novas respostas para questões vinculadas às experiências das camadas mais vulneráveis da sociedade brasileira, pela via do fortalecimento da democracia, das políticas públicas, do acesso coletivo e gratuito a bens e serviços sociais; ao reconhecimento das desigualdades raciais, de gênero e de classe, estabelecendo trincheiras contra elas em uma militância contínua e cotidiana em todas 
as esferas da vida social, tendo como horizonte de nossa práxis a liberdade no sentido posto por Chauí (2000),

\begin{abstract}
A liberdade é a capacidade para darmos um sentido novo ao que parecia fatalidade, transformando a situação de fato numa realidade nova, criada por nossa ação. Essa força transformadora, que torna real o que era somente possível e que se achava apenas latente como possibilidade, é o que faz surgir uma obra de arte, uma obra de pensamento, uma ação heroica, um movimento antirracista, uma luta contra a discriminação sexual ou de classe social, uma resistência à tirania e a vitória contra ela (2000, p. 3).
\end{abstract}

Para tanto, faz-se necessário revisitar as políticas públicas com olhar crítico, percebendo sempre a mutabilidade incontrolável do tempo. A cada nova geração, novos desafios são somados e, por essa razão, é preciso colocar sempre a realidade vivida como ponto de partida para novas esperanças. Afinal, reconhecer até que ponto as reivindicações dos movimentos sociais têm sido apropriadas pelas agendas de governo é algo essencial.

\begin{abstract}
As políticas públicas são iniciativas sustentadas pela sociedade que visam à redistribuição dos benefícios produzidos por todas e todos. Assim, a riqueza (material e imaterial) produzida deve ser, através delas, repartida entre os diferentes grupos sociais de forma equitativa, visando melhorar sua qualidade de vida e também possibilitar a geração de mais riquezas materiais e simbólicas. As políticas públicas são também importantes instrumentos para correção das injustiças sociais. Uma vez que podem induzir e produzir profundas mudanças através da liderança, do exemplo e da ação constante e firme na redução de desigualdades, das discriminações e para a mudança ideológica. Para que possam alcançar o objetivo de correção de injustiças e proporcionar igualdade, as políticas públicas devem contar com alguns elementos básicos (WERNECK, 2010, p. 12).
\end{abstract}

Se por um lado as mulheres negras vêm ocupando espaços anteriormente negados na sociedade, por outro lado, as bases que sustentam as desigualdades continuam rígidas e presentes. O acesso ao nível superior de ensino possibilita uma compreensão ampliada da condição de si e do mundo e incentiva a participação em movimentos sociais. Gerações de mulheres negras que se dedicaram a construir um mundo mais justo e igualitário com respeito às diversidades fazem das desigualdades de gênero, raça e classe parte constante de suas agendas de luta.

Cada geração, que em sua trajetória de vida conquista o acesso às políticas públicas, tem a possibilidade de quebrar as cadeias de subordinação que acompanharam seus pais, seus avós e todos os seus antepassados no pós-diáspora africana. O acesso de mulheres negras na política partidária e a ocupação de lugares nas Câmaras Municipais, Estaduais, Federal e no Senado, ou no Executivo, mostra que ao longo de 50 anos as mudanças no país foram significativas, especialmente com base no governo do Partido dos Trabalhadores.

Logo, este estudo justifica-se pela possibilidade de ampliar o olhar sobre as questões de gênero, classe e raça frente ao acesso aos bens e serviços públicos, materiais e simbólicos, em especial aos direitos do trabalho, trazendo mais equidade sobre a trajetória de vida das mulheres negras. Segundo Piovesan (2006), as discriminações contra as mulheres, a população afrodescendente e indígena, geram a "feminilização e etnicização da pobreza". Por isso, as políticas públicas de proteção e promoção dos direitos humanos requerem um caráter universalista, mas também a abertura às especificidades dos diferentes grupos que formam a 
população brasileira, com suas características, demandas, identidades e culturas particulares, sem que isso implique em fragmentação política e ausência de solidariedade social.

\section{REFERÊNCIAS}

ALBERTI, Verena. História oral: a experiência do CPDOC. Rio de Janeiro: Editora da Fundação Getúlio Vargas, 1990.

ALMEIDA, Érica Terezinha Vieira de; MONTEIRO, Rayana de Sá. A Assistência Social como Política de enfrentamento da Pobreza no Brasil: algumas problematizações a partir do Programa Bolsa Família em Campos dos Goytacazes. Vértices, Campos dos Goitacazes, v. 13, p. 07-29, 2011.

ALMEIDA, Érica Terezinha Vieira de. Assistência Social: universalização do direito ou assistencialização? - problematizando o significado atual da Assistência Social no enfrentamento da "questão social" no município de Campos dos Goytacazes/RJ, 2009 a 2012. UFF/NETRAD: Campos dos Goytacazes, 2012.

ALMEIDA, Érica Terezinha Vieira de; RANGEL, Etuany Martins. Trabalho e reprodução das famílias de trabalhadores beneficiários do bolsa família em Campos dos Goytacazes/ RJ. Vértices. Instituto Federal de Educação, Ciência e Tecnologia Fluminense. v. 16, n. 2, set./dez. 2014. Disponível em: http://pesquisadores.uff.br/academic-production/trabalho-ereprodu $\% \mathrm{C} 3 \% \mathrm{~A} 7 \% \mathrm{C} 3 \% \mathrm{~A} 3 \mathrm{o}$-das-fam $\% \mathrm{C} 3 \% \mathrm{ADlias}$-de-trabalhadores-benefici $\% \mathrm{C} 3 \% \mathrm{~A} 1$ riosdo-bolsa. Acesso em: 24 abr. 2021.

ALMEIDA, Érica Terezinha Vieira de; ILDEFONSO, Pauline Aparecida. Classe, Gênero e Raça - as trabalhadoras negras na cidade de Campos dos Goytacazes/RJ. Boletim Petróleo, Royalties e Região, Campos dos Goytacazes. Rio de Janeiro, ano XV, n. 58, dezembro/2017. Disponível em: https://royaltiesdopetroleo.ucam-campos.br/boletins/boletim-dezembro-2017. Acesso em: 21 jul. 2020.

ANTUNES, Ricardo; ALVES, Giovanni. As mutações no mundo do trabalho na era da mundialização do capital. Educação e Sociedade, Campinas, v. 25, n. 87, p. 335-351, mai./ ago. 2004.

BASTIDE, Roger; FERNANDES, Florestan. Brancos e Negros em São Paulo. São Paulo: Global, 2008.

BENETTI, Pablo. Unificação do mercado de trabalho rural/urbano. In: PIQUET, R. (org.). Acumulação e pobreza em Campos: uma região em debate. Rio de Janeiro: UFRJ, 1986. p. 48-67.

CANDAU, Vera Maria (Coord.). Somos todas iguais? Escola, discriminação e educação em direitos humanos. Rio de Janeiro: DP\&A, 2003.

CHAUÍ, Marilena. Convite à Filosofia. São Paulo: Ática, 2000.

COLLINS, Patrícia Hill. Aprendendo com a outsider within: a significação sociológica do pensamento feminista negro. Revista Sociedade e Estado, v. 31, n. 1, p. 99-127, jan./abr. 2016.

COLLINS, Patrícia Hill. Em direção a uma nova visão: raça, classe e gênero como categorias de análise e conexão. In: MORENO, Renata. (org.). Reflexões e práticas de transformação feminista. São Paulo: SOF, 2015. 
COLLINS, Patrícia Hill. Pensamento Feminista Negro: conhecimento, consciência e a política do empoderamento. Tradução de Jamille Pinheiro Dias. 1. ed. São Paulo: Boitempo, 2019.

CRENSHAW, Kimberle. Demarginalizing the Intersection of Race and Sex: A black Feminist Critique of Antidiscrimination Doctrine, Feminist Theory and Antiracist Politics. University of Chicago Legal Forum, v. 1989, p. 139-167, 1989.

CRENSHAW, Kimberle. Documento para o encontro de especialistas em aspectos da discriminação racial relativos ao gênero. Revista Estudos Feministas, Florianópolis, UFSC, v. 10, n. 1, p. 171-188, 2002.

CRUZ, José Luis Vianna da. Análise do perfil ocupacional da população de baixa renda de Campos dos Goytacazes/RJ. In: PIQUET, R. (org.). Acumulação e pobreza em Campos: uma região em debate. Rio de Janeiro: UFRJ, 1986. p. 29-47.

CRUZ, José Luis Vianna da. Mercado de trabalho e exclusão em Campos/RJ. Boletim Técnico do SENAC, Rio de Janeiro, v. 18, n. 3, p. 159-176, set./dez. 1992.

CRUZ, José Luis Vianna da. Projetos nacionais, elites locais e regionalismo: desenvolvimento e dinâmica territorial no Norte Fluminense entre 1970 e 2000. 2003. 340f. Tese (Doutorado em Planejamento Urbano e Regional) - IPPUR/UFRJ, Rio de Janeiro, 2003.

DAVIS, Ângela. Mulheres, raça e classe. Tradução livre. Plataforma GUETO, 2013.

FALQUET, Jules. Repensar as relações sociais de sexo, classe e "raça" na globalização neoliberal. Mediações, Londrina, v. 13, n. 1-2, p. 121-142, jan./jun. e jul./dez. 2008.

FARIA, Tereza Peixoto. Configuração do Espaço Urbano da Cidade de Campos dos Goytacazes, após 1950: novas centralidades velhas estruturas. In: ENCONTRO DE GEÓGRAFOS DA AMÉRICA LATINA: DO LABIRINTO DA SOLIDÃO AO ESPAÇO DA SOLIDARIEDADE. 5. Anais[...]. Faculdade de Filosofia, Letras e Ciências Humanas da Universidade de São Paulo, São Paulo, p. 78-99, 2005.

GONZALEZ, Lélia. Cultura, etnicidade e trabalho: efeitos linguísticos e políticos da exploração da mulher. In: ENCONTRO NACIONAL DA LATIN AMERICAN STUDIES ASSOCIATION PITTSBURGH. 8. 1979, Pittsburgh. Anais[...]. Pontifícia Universidade Católica do Rio de Janeiro, abr. 1979.

HIRATA, Helena. Gênero, classe e raça: Interseccionalidade e consubstancialidade das relações sociais. Revista Tempo Social, São Paulo, v. 26, n. 1, 2014. Disponível em: https://www. revistas.usp.br/ts/article/viewFile/84979/87743. Acesso em: 24 abr. 2021.

HIRATA, Helena. O Trabalho de Cuidado: comparando relações de cuidado: Brasil, França e Japão. SUR 24, v. 13, n. 24, p. 53-64, 2016.

HIRATA, Helena; KERGOAT, Danièle. Novas Configurações da Divisão Sexual do Trabalho. Cadernos de Pesquisa, v. 37, n. 132, p.595-609, set./dez. 2007.

HOOKS, Bell. Da margem ao centro. Boston: South End Press, 1984. In: FILHO, N. A. (org.). Desenvolvimento e dependência: cátedra Ruy Mauro Marini. Brasília: IPEA, 2013.

IBGE - INSTITUTO BRASILEIRO DE GEOGRAFIA E ESTATÍSTICA. Ministério do Planejamento, Orçamento e Gestão. Censo Demográfico - 2010: Características da população e dos domicílios. Resultados do universo. Rio de Janeiro: IBGE, 2011. 
IPEA - INSTITUTO DE PESQUISA ECONÔMICA APLICADA. Retrato das desigualdades de Gênero, raça e classe no Brasil. Brasília: Ipea, 2017. Disponível em: http://www.ipea.gov. br/retrato/apresentacao.html. Acesso em: 24 abr. 2021.

JESUS, Marize Conceição. O regime militar e a questão racial: o interdito. ENCONTRO DE HISTÓRIA DA ANPUH-RIO. 17. Anais [...]. UFRRJ, Nova Iguaçu, Rio de Janeiro, 2016 Disponível em: http://www.encontro2016.rj.anpuh.org/resources/anais/42/1465860689_ ARQUIVO_TEXTOCOMPLETOPARAANPUH.pdf. Acesso em: 24 abr. 2021.

KERGOAT, Danièle. Dinâmica e consubstancialidade das relações sociais: Novos estudos, n. 86, mar. 2010. Disponível em: http://www.scielo.br/pdf/nec/n86/n86a05.pdf. Disponível em: 24 abr. 2021.

KERGOAT, Danièle. "O cuidado e as imbricações das relações sociais". In: ABREU, Alice Rangel de Paiva; HIRATA, Helena; LOMBARDI, Maria Rosa (Org.). Gênero e trabalho no Brasil e na França: perspectivas interseccionais. São Paulo: Boitempo, 2016.

LÖWY, Michael. A teoria do desenvolvimento desigual e combinado. Outubro, n. 1, 1998, p. 73-80.

MARINI, Ruy Mauro. Dialética da dependência. 10 ed. México: Editora Era, 1990.

MARUANI, Margaret; MERON, Monique. Como contar o trabalho das mulheres? França 1901-2011. In: PAIVA, Alice Rangel; HIRATA, Helena; LOMBARDI, Maria Rosa. (org.). Gênero e Trabalho no Brasil e na França: Perspectivas interseccionais. Tradução de Carol de Pádua. ed. 1. São Paulo: Boitempo, 2016.

MORENO, Renata. Entre o capital e a vida: pistas para uma reflexão feminista sobre as cidades. In: MORENO, Renata. (org.). Reflexões e práticas de transformação feminista. São Paulo: SOF, 2015. (Coleção Cadernos Sempreviva. Série Economia e Feminismo, 4). Disponível em: http://www.sof.org.br/wp-content/uploads/2016/01/ reflex $\% \mathrm{C} 3 \% \mathrm{~B} 5$ esepraticasdetransforma $\% \mathrm{C} 3 \% \mathrm{~A} 7 \% \mathrm{C} 3 \% \mathrm{~A} 3$ ofeminista.pdf. Acesso em: 24 abr. 2021.

NEVES, Delma Pessanha. Mudança tecnológica e emprego. In: PIQUET, R. (org.). Acumulação e pobreza em Campos: uma região em debate. Rio de Janeiro: UFRJ, 1986. p. 86-103.

NEVES, Delma Pessanha. A perversão do trabalho infantil. Niterói: Intertexto, 1999.

NEVES, Delma Pessanha. A pobreza como legado: O trabalho infantil no meio rural da sociedade brasileira. Revista de História Regional, v. 6, n. 2, p. 149-173, Inverno 2000/2001.

NEVES, Delma Pessanha. Campesinato e reenquadramento sociais: os agricultores familiares em cena. Revista NERA. Presidente Prudente, ano 8, n. 7, p. 68-93, jul./dez. 2005.

OIT/GRPE - ORGANIZAÇÃO INTERNACIONAL DO TRABALHO. Gênero, raça, pobreza e emprego: o Programa GRPE no Brasil. Programa de Fortalecimento Institucional para a Igualdade de Gênero e Raça, Erradicação da Pobreza e Geração de Emprego (GRPE). Brasília: OIT - Secretaria Internacional do Trabalho, 2016. Disponível em: https://www.ilo.org/ brasilia/publicacoes/WCMS_226572/lang--pt/index.htm. Acesso em: 11 set. 2017.

PAIXÃO, Marcelo; CARVANO, Luiz Marcelo (org.). Relatório Anual das Desigualdades Raciais no Brasil; 2007-2008: Constituição Cidadã, seguridade social e seus efeitos sobre as assimetrias de cor ou raça. UFRJ: LAESER, 2010. 
PIOVESAN, Flávia. Direitos Humanos e o Direito Constitucional Internacional. In: Caderno de Direito Constitucional - 2006. Disponível em: http://www.dhnet.org.br/direitos/militantes/ flaviapiovesan/piovesan_dh_direito_constituciona 1.pdf. Acesso em: 24 abr. 2021.

PISCITELLI, Adriana. Carinho, limpeza e cuidado: experiências de imigrantes brasileiras. In: PAIVA, Alice Rangel; HIRATA, Helena; LOMBARDI, Maria Rosa. (org.). Gênero e Trabalho no Brasil e na França: Perspectivas interseccionais. Tradução de Carol de Pádua. ed. 1. São Paulo: Boitempo, 2016.

REIS, Maria Clareth Gonçalves. Mulheres, negras e professoras: suas histórias de vida. Rio de Janeiro: Brasil Multicultural, 2017.

RIBEIRO, Rafaela M. O negro e seu mundo: Vida e trabalho no pós-Abolição em Campos dos Goytacazes (1883-1893). Campos dos Goytacazes. Dissertação (Mestrado em Sociologia Política). Universidade Estadual do Norte Fluminense, 2012.

SILVA, Simone Rezende da. Quilombos no Brasil: a memória como forma de reinvenção da identidade e territorialidade negra. COLOQUIO INTERNACIONAL DE GEOCRÍTICA. 12. Anais[...]. Universidad Nacional de Colombia, Facultad de Ciencias Humanas, Bogotá, 7 a 11 de maio de 2012.

WERNECK, Jurema. Políticas públicas para mulheres negras. Passo a passo: defesa, monitoramento e avaliação de políticas públicas. Rio de Janeiro: Criola, 2010. 